\title{
Regional Disparities in the Training Market: Opportunities for Adolescents to Obtain a Company-Based Training Place Depending on Regional Training Market Conditions
}

\author{
Christian Michaelis, Robin Busse \\ Georg-August University of Göttingen, Platz der Göttinger Sieben 5, 37073 Göttingen
}

Received: 28 July 2020, Accepted: 21 January 2021

\begin{abstract}
Context: Due to limited geographical mobility, opportunities for adolescents interested in company-based training are primarily dependent on regional training offers. Competition for company-based training among adolescents varies regionally, and thus, the chance to obtain a training contract varies as well. In this article, we investigate the opportunities for adolescents to obtain company-based training depending on regional training market conditions. We assume that the advantages of obtaining a company-based training place exist in areas of decreased competition among interested adolescents. However, the question is whether those advantages will differ between adolescents depending on characteristics such as school achievement, socioeconomic status or migration background. Furthermore, we assume that, above all, market-induced ease-of-access to company-based training exists for occupations that face hiring challenges and indicates less occupational attractiveness.
\end{abstract}

Methods: The transition from school (after 9th and 10th grade) to company-based training is analysed using data from the German National Educational Panel Study (NEPS, starting cohort 4). This dataset is merged with the official regional training market data regarding local supply and demand ratio for training places (called "SDR") in the dual system of Vocational Education and Training in Germany. Logistic regressions are used to predict the probabilities of obtaining a training place. The focus lies on the interaction effects between

*Corresponding author: christian.michaelis@wiwi.uni-goettingen.de 
SDR and adolescents' education-related characteristics (school certificates and grade point average), socioeconomic characteristics and migration backgrounds. Subgroup-specific analyses of different clusters of hiring challenges for trainee occupations are used to examine whether these effects are valid for all occupations.

Findings: The results confirm regional differences in obtaining a training place depending on the SDR. Here, applicant hierarchies according to educational achievement continue to exist if competition for company-based training among adolescents decreases. Beneficiaries are better-qualified adolescents with poorer GPAs. SDR hardly influences social disparities. However, the advantages of obtaining a company-based training place primarily exist for training occupations with hiring challenges when competition for company-based training among adolescents decreases. These occupations have a significantly lower occupational prestige (ISEI-08) compared to occupations with fewer hiring challenges.

Conclusion: The results make it clear that market-induced ease-of-access to company-based training is not necessarily an advantage. Because the findings indicate that the advantages pertain mainly to low-prestige occupations, it can be assumed that career-path disadvantages can arise down the road. Future studies should investigate this in more differentiated ways.

Keywords: Access to Education and Training, Equal Opportunity, Dual System, Training Market, Statistical Analysis, Vocational Education and Training, VET

\section{Introduction}

Several countries (for example, Austria, UK-England, Finland, Germany, Hungary, and Switzerland) implemented Vocational Education and Training (VET) systems in cooperation with companies (European Centre for the Development of Vocational Training (CEDEFOP), 2018; Poulsen \& Eberhardt, 2016). The companies benefit from this system as their direct involvement and commitment to the training process meets their demand for skilled workers (Poulsen \& Eberhardt, 2016). For adolescents, vocational training is crucial because it has been regarded as an initiator of vocational careers. Depending on the type of the training system, which differs between countries, adolescents could acquire their first vocational skills; most systems even enable the acquisition of formal qualifications (European Commission, 2012; The Organization for Economic Co-operation and Development [OECD], 2010). Participating in a VET could initiate several positive labour market outcomes for adolescents, including a faster transition into employment, a higher probability of first-job stability and less risk of employment with a qualification mismatch (CEDEFOP, 2013). Thus, adolescents' potential for individual occupational adjustments as well as the further guarantee of social 
status and equal opportunity depends on this phase of life (Baethge et al., 2006). There is a large amount of evidence of the conditions necessary to achieving a company-based training place (see, for example, Beicht \& Walden, 2017, 2018, 2019; Forsblom et al., 2016; Glauser \& Becker, 2016; Goastellec \& Ruiz, 2015; Holtmann et al., 2017; Seeber et al., 2019a). However, international research on obtaining a company-based training place has paid little attention to the effects of regional conditions within countries (like regional demography, educational context or economic structure) or shows mixed evidence (Holtmann et al., 2017). Nevertheless, investigating these effects has to be seen as important because the geographical mobility of adolescents interested in VET is often limited. For example, a lack of family support and financial resources or a poorly developed mobility infrastructure can impede the willingness of an adolescent to accept a training contract in a more remote region. Thus, due to mobility restrictions, adolescents often have to apply to regional training places.

Access to company-based training differs by country due to the different governance structures in the training market. In many countries, the signing of a training contract is common (European Commission, 2012; OECD, 2010; Poulsen \& Eberhardt, 2016). The initiation processes of contracting and the participation of contracting parties often differ by countries. In addition to companies and applicants, in some countries, state institutions (e.g. schools) can be involved in hiring decisions and training contracts. Public subsidy programmes such as training-place guarantees can also regulate the training market. Marketmediated VET systems with training markets, which have a governance structure based on regular labour market characteristics, primarily exist in Germany, Austria and Switzerland (OECD, 2010; Kleinert et al., 2018). In these countries, adolescents actively apply to training places, and companies are responsible for their recruitment. Training contracts are finalised between companies and applicants by mutual agreement. Similar to traditional labour markets (see e.g. Borjas, 2013), the supply and demand for training places in such systems are usually not well-balanced in regional training markets. On the one hand, an imbalance can exist if the demand for training places (by adolescents) cannot be adequately satisfied by the supply side (by employer, i.e., excess demand). This situation is characterized by a high level of competition for company-based training among adolescents. On the other hand, the supply of company-based training may exceed demand (i.e., excess supply). In this case, adolescents can benefit if companies are confronted with hiring challenges due to fewer suitable applicants. Thus, companies are faced with the decision of keeping training places vacant or adjusting their hiring standards. ${ }^{1}$ However, as long as a sufficient number of unsuccessful applicants remain available in the training market, one option that companies have is to downgrade the expected requirement profile of applicants. As a result, the chance to obtain a

1 From a long-term perspective, companies have to reconsider recruitment strategies and enhance the attractiveness of their vacant positions (Wieling \& Borghans, 2001). 
training place depends not only on the adolescents' performance potential but on the regional supply and demand for training places as well.

For example, in the German training market, current empirical analyses reveal that there are advantages for adolescents wishing to obtain a company-based training place when there is a higher ratio of supply and demand for company-based training in the regional training market (Beicht \& Walden, 2017; Eckelt \& Schauer, 2019; Lex \& Zimmermann, 2011). The question is whether these general advantages apply to all adolescents interested in company-based training. The analyses of regional disparities, however, requires consideration of complex interaction effects. Eckelt and Schauer (2019) report that individuals without higher education entitlements can benefit from an excess supply of training places if they achieved a graduation certificate in comparison to an adolescent who left school without a school certificate. This is surprising, because it shows that the extent to which school certificates affect the access to VET depend on regional differences. Nevertheless, a more differentiated view of adolescents' characteristics (e.g., grades, migration and parental background) and their interaction with the regional conditions of the training market is necessary and can enhance the current research (Baethge et al., 2016; Kleinert et al., 2018). Additionally, it must be supposed that the advantages for VET-interested adolescents are more pronounced for less attractive occupations when competition for company-based training among adolescents decreases. One indicator of attractiveness is the share of vacancies of training places in an occupation which indicates hiring challenges. Therefore, it is assumed that occupations characterized by hiring challenges are less attractive and provide easier access to company-based training, particularly when competition for company-based training among adolescents decreases.

This contribution seeks to shed more light on these research gaps and investigates the following research questions:

- To what extent do different regional training market conditions affect adolescents' access to company-based training in market-mediated training systems?

- Do those effects interact with adolescents' characteristics?

- Do those effects differ between different clusters of hiring challenges for companybased training programmes? 


\section{Understanding the Matching Process in the Training Market}

Matching in training markets is a complex process and is influenced by several frictions. Following general assumptions of matching function in labour markets companies as well as adolescents have to handle with different information imperfections, like identifying potential training contract partners and their heterogeneities (Petrongolo \& Pissarides, 2001). Therefore, the commitment of adolescents and training providers in search and recruiting process is a critical success factor of the matching process (e.g. Diamond, 1982; Mortensen, 1982). This means, both, training providers and adolescents, have to engage and signal the willingness to enter in a training contract. Therefore, access to a training place is seen as a complex interplay of self- (i.e., the adolescent) and external- (i.e., company-based conditions and training-market conditions) selection mechanisms. The major preconditions for a successful training contract are the offer of a training place from a company, a training intention by an adolescent and the acceptance on specific contract agreements by both parties.

In brief, an adolescent's decision to apply for a company-based training place is shaped by individual, institutional, and regional constraints and opportunities (Glauser \& Becker, 2016) as well occupational preferences, interests (e.g., Holland, 1997), and outcome expectations (e.g., Lent et al., 1994). ${ }^{2}$ If adolescents choose a company-based training place over other available educational options, the success of their application, however, is primarily determined by the training companies. ${ }^{3}$

In general, for marked-mediated training places companies aim to ensure the best possible choice of applicants to fill their training places. Consequently, it is important to ensure that the company training strategy, the training requirements and the personality traits of the applicants (especially their competencies) are a good match. These imperatives are also important for minimizing any issues that may arise between the training seekers and providers during the training process. According to the assumptions of the job competition model (Thurow, 1972, 1975), applicants are ranked (in job queues) by their potential as workers on a scale from best to worst. A training offer is given to those who are expected to fulfil the highest expectations of the company. Therefore, companies use different signals (i.e., changeable attributes proven by school certificates or work references) and indices (i.e., unchangeable attributes, such as gender) as selection criteria for the applicants (Spence, 1973). Even if an adolescent has a relatively short curriculum vitae $(\mathrm{CV})$, a variety of information is already evident in their school certificates, which will be used to estimate their suitability. Schuler et al. (2007) show that it is common to screen application documents for company-based training places. In this regard, school certificates and grades are important (Forsblom et al., 2016).

2 Regarding the development of occupational preferences, an integrated perspective of sociological and psychological theories is required (for an overview, see Brown \& Lent, 2013).

3 Obviously, an adolescent can also reject the offer of a training contract. Nevertheless, companies have a more favourable market situation as they can evaluate applications simultaneously, compare applicants and react more easily to unrealised contracts with their preferred candidates. 
Studies in Germany show that the higher the applicant's level of education, the more likely it is that they will obtain a training contract (e.g., Autorengruppe Bildungsberichterstattung, 2018; Busse, 2020a, 2020b; Holtmann et al., 2017; Protsch \& Dieckhoff, 2011). Additionally, it is well known that better grades favour obtaining a training place (e.g., Beicht \& Walden, 2017; Busse, 2020a, 2020b; Holtmann et al., 2017; Protsch \& Solga, 2015). From a theoretical point of view, companies' selection practices can partly explain the (re)production of social inequalities as a result of the market-based inclusion mechanism. Numerous studies report social and migration-related disparities in school-leavers' access to company-based training (Seeber et al., 2019a). The influence of social origin on students' access to company-based training can be partially revealed in the resources relevant for the access to VET (human, social and cultural capital); migrants are more likely to have a lower socioeconomic status (SES). Due to effects (the link between social background and school performance, Boudon, 1974), adolescents with low SES, as well as young immigrants, are less likely than adolescents with high SES or non-migrants to be successful in school in general. The label "no or low school-leaving certificates" has been proven to be an obstacle for school-leavers' access to VET (Holtmann et al., 2017; Seeber et al., 2019a). The primary effects of social origin and migrant background also lead to differences in the resources available to applicants for company-based training (Beicht \& Walden, 2019). Therefore, it can be assumed that companies are more likely to rank low-SES adolescents and immigrants in lower positions in the application queue.

\section{Fostering Disparities due to the Regional Training Market Situation}

The regional nature of the training market reflects the complex effects of the contextual mechanisms of the training system. On the one hand, the regional economic structure and performance (industrial and occupational structure, enterprise density, company sizes, etc.) primarily determine the qualitative and quantitative structure of the supply side. On the other hand, the adolescents interested in VET constitute the demand side (influenced in particular by demography, level of education, and training alternatives; Bundesinstitut für Berufsbildung [BiBB], 2018; Seeber et al., 2019b). Regional training market conditions may restrict or improve an individual's opportunity to achieve a training place (Baethge et al., 2016; Busse, 2020b; Eckelt \& Schauer, 2019; Weßling et al., 2015). From the perspective of adolescents interested in company-based training, regional competition is a central factor that affects the chance to obtain a training place. Previous studies have already shown that a higher relationship of supply with the demand for training places fosters opportunities for obtaining a company-based training place (Beicht \& Walden, 2017; Lex \& Zimmermann, 2011). Therefore, it is assumed: 
$\mathrm{H} 1$ : The chances of obtaining a company-based training place increases when there is reduced regional competition for company-based training among adolescents.

Theoretical assumptions regarding application hierarchies continue to apply to training market situations characterized by reduced competition for company-based training among adolescents. In this regard, Eckelt and Schauer (2019) show that advantages exist primarily for better-qualified adolescents. We aim to expand the state of research and consider that obtaining a training place depends on the interactions between educational qualifications and grade point average (GPA).

H2a: Better-qualified adolescents continue to have the highest probability of obtaining a training place if regional competition for company-based training among adolescents decreases.

$\mathrm{H} 2 \mathrm{~b}$ : If regional competition for company-based training among adolescents decreases, the first to benefit are the better-qualified adolescents with poorer GPAs. Lower-qualified adolescents only benefit if they have a better GPA.

Additionally, we assume that social and migration-related disparities are more pronounced in regional training market conditions characterized by a higher competition for companybased training among adolescents. To our knowledge, existing research provides no evidence for the link between regional training market conditions on the one hand, and social and migration-related disparities in access to VET on the other hand.

H3: Social and migration-related disparities in access to company-based training are more likely to occur in regional training markets with increased competition.

We believe that the advantages of obtaining a training place due to reduced regional competition among VET-interested individuals do not apply to the full range of occupations. From the perspective of market allocation, the most attractive training places are filled when there is insufficient demand. This means that advantages in accessing training places should be more likely for those occupations that are already characterized as having hiring challenges. In previous research, this aspect was not considered. Therefore, we assume:

H4: The advantages of obtaining a company-based training place due to reduced regional competition for company-based training among adolescents matter for occupations that are affected by hiring challenges. 


\section{Method}

\subsection{The German Dual System as a Research Object}

To verify the hypothesis, we examined the German training market as the object of analysis. In Germany, two full qualification training systems exist. Most full qualification VET programmes can only be completed through the German dual training system (326 training programmes in 2018, [BiBB, 2018]; see [Solga et al., 2014] for an overview of Germany's VET structure). The dual training system is given a high priority as it provides a large proportion of Germany's first-time vocational qualifications; in 2018, for example, 492,668 trainees entered the dual training system (Autorengruppe Bildungsberichterstattung, 2020). The system is called dual because economic as well as public institutions are responsible for the training programmes, with the learning venues shared between companies (e.g. in the private and public sector as well as public administration) and vocational schools. In accord with companies' involvement, access to dual training places is controlled by the training market. Officially, there are no prerequisites for applicant qualification in the dual training system. However, despite this, the dual training system is predominated by trainees with intermediate secondary school certificates (which are intermediate general educational qualifications); for example, entering trainees in 2016 possessed an intermediate secondary school certificate (47.4\%); no or a lower secondary school certificate (27.4\%); or a university entrance qualification (22.9\%) (Autorengruppe Bildungsberichterstattung, 2018). In Germany, there is also a full-time school-based VET system (2018: 215,819 entering trainees [Autorengruppe Bildungsberichterstattung, 2020]). Most training programmes are focused on the public sector (especially for the fields of health, education and social services). The selection of apprentices takes precedence over the examination of their formal requirements, such as school certificates (Michaelis, 2017). Because control mechanisms and access conditions for the full-time school-based VET systems differ from those of the dual training system, the full-time schoolbased VET system is not considered in this paper.

The relation of supply and demand in the German training market is not balanced. Excess demand for training places existed for years in Germany, but the nation has experienced a trend of decreasing competition between applicants in recent years. For example, in 2012, 100 applicants were faced, on average, with 93.2 training places; in 2017, this increased to 94.8 training places (BIBB, 2013, 2018). These dates are based on official statistics. It should be assumed that the real supply and demand is higher because not every training place and VET-interested adolescent registers at the Federal Labour Office. Nevertheless, regional analyses make it clear that the relationships between supply and demand differ between training market regions (Autorengruppe Bildungsberichterstattung, 2012; BiBB, 2018). Excess demand conditions exist in numerous western German regions while excess supply for trai- 
ning places exists mainly in southern regions (Bavaria, Baden-Wuerttemberg) and eastern German federal states. In this regard, some studies show that access to the German dual training system may differ between local training regions (Eckelt \& Schauer, 2019; Hillmert et al., 2017). Additionally, event-history analyses even show that regional differences are, thus far, more influential than temporary crises in the German labour market in relation to gaining entry into dual training (Hillmert et al., 2017).

\subsection{Data}

For the following analyses, the Starting Cohort 4 (SC4, version 10.0.0) of the National Education Panel (NEPS) is used (Blossfeld et al., 2011). This dataset contains 16,425 9thgrade pupils in Germany who were interviewed using a longitudinal study design starting in autumn 2010 (wave 1). Their individual development and educational and employment experiences comprise the subjects of these interviews. The cohort is only partially representative of 9th-grade pupils in Germany. In this dataset, pupils in lower secondary education (23.2\% of wave 1 ), special needs schools (7.2\% of wave 1 ) and comprehensive schools $(17.2 \%$ of wave 1) are over-represented (Steinhauer \& Zinn, 2016). This is advantageous for this contribution. Hence, the chances of lower-educated adolescents entering dual training could be investigated more precisely. ${ }^{4}$

The dataset is limited to graduates and school-leavers from general educational schools who graduated/left after the 9th or 10th grade. This limitation is necessary, as matching problems concerning dual training programmes are more likely in this cohort.

The NEPS dataset includes different aspects of the CV (e.g., school episodes, pre-vocational programmes, vocational and higher education programmes, military enlistments, employment and unemployment, parental leave episodes, internships and gaps). The CV episodes of each study participant are sorted chronologically by their respective start dates. In the dataset, there exists no direct variable with information regarding school-leavers according to the grade level. Thus, the target group has to be determined approximatively. To do this, school-leavers were identified based on their recorded grade level for each wave of the survey as well as the type of school visited at the time. If a NEPS participant left a Hauptschule (lower secondary school), Realschule (secondary school), Haupt- and Realschule (a combined school), Gymnasium (school to obtain a university entrance qualification), comprehensive school, Waldorfschule (common private school in Germany) or special needs school within the first seven waves and obtained no university entrance qualification in a general education programme, the participant was scored as a school-leaver after the 9th and 10th grade. In total, there were 6,561 school-leavers: $5.0 \%$ had no educational qualification, $4.9 \%$ left with an

4 In relation to the representativeness of the sample, it is important to use a weighting factor for descriptive distributions. Thus, a calibrated cross-sectional weight is used which refers to the representativeness of 9 th graders in wave 1. 
exam certificate from a special needs school (German: "Sonder- oder Förderschulabschluss"), 22.5\% had a regular lower-secondary school certificate (German: "Hauptschulabschluss"), $13.8 \%$ had a qualified lower-secondary school certificate, and $53.8 \%$ had an intermediate secondary school certificate (German: "mittlerer Bildungsabschluss") (distribution without weighting factor).

\subsection{Dependent Variables}

The initial entry into the German VET system is considered. A successful dual training applicant is one who achieved a position in a skilled labour training or a dual training programme. Here, all persons are excluded who entered into a full-qualifying school-based VET program or non-company-based training programme or who started a training programme abroad.

The identification of unsuccessful training applicants is not possible in the NEPS dataset. Although there were retrospective interviews to determine whether an NEPS participant applied for a training place, this variable has several problems because it includes missing values, does not contain any information about the application date and includes applications for the full-qualifying school-based VET system. Therefore, for this analysis, NEPS participants are considered to be a reference group that entered into pre-vocational programmes in the transition sector ${ }^{5}$ after leaving general school (9th and 10th grade). Due to compulsory schooling regulations in Germany, adolescents enter into these programmes (in most federal states) if they are interested in training but have not received a training place, or in some cases, if they have not fulfilled their compulsory education requirements.

The dependent variable thus measures the initial entry into a dual training place or prevocational programme of the previously described sample. All the previously described adaptions reduced the sample size to 4,608 adolescents (dual training sector: 2,874; transition sector: 1,734$)$.

When the months including July to September were used as a starting point for a training year, most trainees started their pre-vocational programme or dual training between summer 2011 and summer 2013 (transition sector: 93.3\%, dual training sector: 91.4\%).

\subsection{Independent Variables}

To measure the impact of competition for company-based training among adolescents on entry into dual training, each NEPS participant receives information on the regional (employment agency district level) competition for training places. Therefore, the relationship between the ratio of supply and demand for training places (SDR) for the training year

5 This sector involves a variety of pre-vocational programmes that allow applicants to enhance their competences and gain work experience through internships in order to improve their chances of entering a full-qualifying VET programme (Solga et al., 2014). 
2012 is used. ${ }^{6}$ In Germany, the SDR is a popular indicator of vocational reporting. It indicates the ratio of dual training opportunities offered (concluded training contracts plus vacant training places) and dual training opportunities requested (concluded training contracts plus vacant adolescents with intentions of obtaining training contracts) in a given training year (BiBB, 2018).

School-leaving certificates are used to differentiate educational achievement after 9th or 10th grade. Three educational qualification categories are distinguished here; the highest qualification level is the "intermediate secondary school certificate" (intermediate educational qualification, in German: "mittlerer Bildungsabschluss"). For low-level educational qualifications, a distinction is made between "no or regular lower-secondary school certificate" (German: "kein Abschluss oder Hauptschulabschluss") and "qualified lower-secondary school certificate" (German: "qualifizierter Hauptschulabschluss")7 ${ }^{7}$ The former includes adolescents without school certificates, adolescents with a certificate given by a special needs school and adolescents with a regular lower-secondary school certificate (this category is the lowest educational level). The student's GPA is used to obtain differentiated information concerning the quality of said school certificates. In Germany, grades are coded from 1 (very good) to 6 (insufficient).

Three different variables are used to achieve information regarding the effects of social disparities. First, a migration background is considered. Therefore, all participants who were born abroad or had at least one parent born abroad are marked as having a migration background. Second, to control the socioeconomic background, parental education (whether both parents achieved no or a lower-secondary school certificate), as well as parents' maximum value on the International Socio-Economic Index 2008 (ISEI-2008, Ganzeboom, 2010), ${ }^{8}$ are considered. Regarding parental maximum ISEI-08 values, a distinction is made between parents who achieved a maximum value of 30 on this scale and parents who achieved a value higher than 30. This threshold has been used because most of the semi-skilled and lowprestige occupations are in the cluster with lower ISEI-08 values.

6 The matching of the NEPS data set with regional SDR values has been performed by the LifBi (Institution for data repository). However, a clear regional identification of NEPS participants for users of the NEPS dataset is generally prohibited (data protection). This would be violated if both annual and region-specific training market data were merged with the NEPS data set. Therefore, only SDR values of the training year 2012 have been merged with the NEPS data set. As described before this does not fully cover the VET start years. Nevertheless, VET monitoring reveals that developments in the training market over two years are only slight. Thus, it is assumed that the resulting bias is low (see e.g. BiBB, 2018).

7 In many federal states exist an extended version of the "lower-secondary school certificate". Depending on federal state specific school law, there are federal state specific provisions for this certificate (for example, a further school year, additional examinations or a certain grade point average). In NEPS all of these forms are labelled as "qualified lower-secondary school certificate". However, for all variants it has been expected that this qualified school certificate fosters the chance to obtain a dual training place.

8 This is an internationally recognised indicator based on the International Standard Classification of Occupations 2008 (ISCO-08). The ISCO-08 classifies occupations according to skill levels and specifications. On this basis, the ISEI-08 calculates a prestige value that considers the expected level of education and future income of an occupation (Ganzeboom, 2010; Ganzeboom et al., 1992). This Index varies between 11.01 and 88.96 . 


\subsection{Control Variables}

The NEPS dataset provides information about the basic cognitive dispositions of said adolescents to obtain a differentiated insight into the abilities of the adolescents in this study. The scales of the Domain General Cognitive Functions (DGFC) are considered (Haberkorn \& Pohl, 2013); the DGFC distinguishes between the dimensions of "reasoning" and "perceptual speed". For ease of interpretation, the DGFC scales were normalised to a mean of 0 , with a standard deviation of 1 . To control the more sophisticated abilities of school-leavers, grades in mathematics and German for the last interim report before entering in VET were also used. Another control variable is the gender variable (reference category: Male adolescents).

Due to the federalism of Germany's educational systems and the fact that educational systems differ between federal states, as well as specific context factors for federal states (economy, demography, etc.), the influence of federal states is controlled in all models. Therefore, dummy variables for the place of school at the level of the federal states are built (15 dummy variables, 1 federal state as reference). However, the data usage contract prohibits the identification of federal state-specific effects. Thus, these effects cannot be reported.

\subsection{Distribution of Independent and Control Variables}

Table 1 includes information about the distribution of independent and control variables (mean/standard deviation).

Table 1: Distribution of Independent and Control Variables (Mean/Standard Deviation)

\begin{tabular}{llll}
\hline \multicolumn{1}{l}{ Total sample } & Dual training & Transition sector \\
\hline Independent variables & & & \\
\hline SDR & $93.901 / 7.094$ & $94.828 / 7.227$ & $92.023 / 6.420$ \\
\hline Qualified lower secondary school certificate & $.128 / .334$ & $.119 / .324$ & $.146 / .353$ \\
\hline No or regular lower-secondary school certificate & $.287 / .452$ & $.175 / .380$ & $.517 / .500$ \\
\hline GPA & $2.708 / .561$ & $2.632 / .524$ & $2.880 / .605$ \\
\hline Migration background & $.249 / .432$ & $.210 / .407$ & $.331 / .471$ \\
\hline Both parents have no or lower secondary school certificate & $.120 / .325$ & $.120 / .325$ & $.119 / .324$ \\
\hline Max. parental ISEI <30 & $.159 / .365$ & $.148 / .355$ & $.181 / .384$ \\
\hline Control variables & & & \\
\hline Grade in mathematics & $3.061 / .926$ & $2.963 / .919$ & $3.28 / .904$ \\
\hline Grade in German & $2.945 / .770$ & $2.903 / .757$ & $3.04 / .792$ \\
\hline Perceptual speed (DGFC) & $.033 / .975$ & $.067 / .960$ & $-.042 / 1.00$ \\
\hline Reasoning (DGFC) & $.128 / .966$ & $.245 / .914$ & $-.126 / 1.03$ \\
\hline Sex (female) & $.396 / .489$ & $.371 / .483$ & $.446 / .497$ \\
\hline Note. Weighted but not imputed data. & & &
\end{tabular}




\subsection{Analysis Strategy}

Logistic regressions are used to analyse the initial entry into a dual training place against the initial entry into the transition sector of 9th and 10th-grade school-leavers. A binomial logistic regression analysis is built up stepwise to verify the hypotheses $\mathrm{H} 1$ to $\mathrm{H} 3$. In the first model, only the influence of the regional situation of the training market (SDR) is examined beside the control variables (M1). The next models (M2) examined a more sophisticated influence of all independent variables (M2) and the interactions of those with the SDR (M3 and M4).

To verify hypothesis $\mathrm{H} 4$, all dual training programmes are clustered towards their value of vacant training places to all offered dual training places in Germany for the year 2012. ${ }^{910}$ This value indicates the extent of the hiring challenges for an occupational group. The entered dual training programmes in the data set varies between .5 and $24.2 \%$ of vacant training places (median $=4.3 \%$, standard deviation $=5.1 \%)$. Dual training starters are clustered in three comparable quantitative clusters: (1.) Low hiring challenges (vacant training places $<=2.5 \%$, ca. $33.6 \%$ of dual training starters), intermediate hiring challenges $(2.5 \%<$ vacant training places $<=5.0 \%$, ca. $32.1 \%$ of dual training starters), higher hiring challenges (vacant training places $>5 \%$, ca. $34.3 \%$ of dual training starters). A multinomial logistic regression is used to prove the influence of the predictors in achieving a training place in one of those groups with different hiring challenges. For a better interpretation of these regression results, potential future outcomes of relating occupations in the hiring challenge differentiated clusters are viewed. In NEPS, each occupation is assigned an ISEI-08 value. As explained above (section 4.4), this is a prestige value that considers the expected level of education and future income of an occupation (Ganzeboom, 2010; Ganzeboom et al., 1992). Thus, in the last step, relating ISEI-08 values of the hiring challenge differentiated clusters are compared.

Interaction terms with metric variables serve the risk to increase multicollinearity. A practical approach is to centre the metric variables of the interaction terms on the mean (Jaccard et al., 2003). Thus, centring on the mean is done for the GPA (mean $=2.71, \mathrm{SD}=.56$ ) and SDR (mean $=93.60, \mathrm{SD}=6.96$ ).

For the model output, the average marginal effects (AMEs) are presented. The AME indicates the average change (of all group-specific observations), in percentage points, of a predictor on the probability of the occurrence of an event (e.g., entry into the dual training system) if the predictor increases by one unit.

9 Due to data availability this clustering is made on higher occupational aggregation, the 3-digital level of the KldB 2010. Therefore, 95 occupational groups could be distinguished in the NEPS data set. The KldB 2010 (German: "Klassifikation der Berufe 2010") is the standard occupational classification system in Germany (Paulus \& Matthes, 2013).

10 In the case of missing in official data, the values of 2013 are used. 
However, interaction terms are difficult to interpret. Therefore, the influence of selected (significant) interactions on the predicted probability of obtaining a dual training place is visualized.

Missing values were estimated by multiple imputation $(n=10)$. A multivariate imputation by chained equations is used. To predict the missing values, all the variables included in the regression model, as well as individual competence values (in mathematics, reading, science and ICT-literacy), are used as predictors.

\section{$5 \quad$ Results}

Table 2 presents the results of a stepwise binomial logistic regression, which are used to explain the initial entry of 9th and 10th-grade school-leavers into dual training places.

Table 2: Binomial Logistic Regression to Explain the Initial Entry of 9th and 10th-Grade SchoolLeavers Into Dual Training Places

\begin{tabular}{|c|c|c|c|c|}
\hline Model & (M1) Regional SDR & $\begin{array}{l}(\mathrm{M} 2)+\text { educational } \\
\text { attainment \& social } \\
\text { disparities }\end{array}$ & $\begin{array}{l}(\mathrm{M} 3)+\text { interaction } \\
\text { terms }\end{array}$ & $\begin{array}{l}(\mathrm{M} 4)+\text { differentiated } \\
\text { educational interaction }\end{array}$ \\
\hline \multicolumn{5}{|c|}{ Regional training market condition } \\
\hline SDR & $.0061^{\star * \star}$ & $.0043^{* *}$ & $.0076^{\star *}$ & $.0076^{\star *}$ \\
\hline \multicolumn{5}{|c|}{ Educational qualification (reference category for the school certificate: intermediate secondary school certificate) and GPA } \\
\hline $\begin{array}{l}\text { Qualified lower } \\
\text { secondary school } \\
\text { certificate }\end{array}$ & & $-0.1791^{* * *}$ & $-0.1839^{* * *}$ & $-0.1848^{* * *}$ \\
\hline $\begin{array}{l}\text { No or regular lower } \\
\text { secondary school } \\
\text { certificate }\end{array}$ & & $-0.3766^{* * *}$ & $-0.3803^{\star * *}$ & $-0.3810^{* * *}$ \\
\hline GPA & & $-.0601^{\star *}$ & $-.0574^{\star \star}$ & $-0.1025^{\star * *}$ \\
\hline \multicolumn{5}{|c|}{ Social background characteristics } \\
\hline Migration background & & $-.0671^{* * *}$ & $-.0676^{\star * *}$ & $-.0687^{* * *}$ \\
\hline $\begin{array}{l}\text { Both parents have no } \\
\text { or lower secondary } \\
\text { school certificate }\end{array}$ & & .0153 & .0200 & .0205 \\
\hline $\begin{array}{l}\text { Max. parental ISEI } \\
<30\end{array}$ & & -.0250 & -.0241 & -.0253 \\
\hline \multicolumn{5}{|l|}{ Interaction terms } \\
\hline $\begin{array}{l}\text { Qualified lower } \\
\text { secondary school } \\
\text { certificate }{ }^{*} \text { GPA }\end{array}$ & & & & $.0859^{*}$ \\
\hline $\begin{array}{l}\text { No or regular lower } \\
\text { secondary school } \\
\text { certificate }{ }^{*} \text { GPA }\end{array}$ & & & & $.0604^{*}$ \\
\hline
\end{tabular}




\begin{tabular}{|c|c|c|c|c|}
\hline $\begin{array}{l}\text { Qualified lower } \\
\text { secondary school } \\
\text { certificate }{ }^{*} \text { SDR }\end{array}$ & & & -.0026 & -.0025 \\
\hline $\begin{array}{l}\text { No or regular lower } \\
\text { secondary school } \\
\text { certificate }^{*} \text { SDR }\end{array}$ & & & $-.0066^{\star *}$ & $-.0065^{\star *}$ \\
\hline $\mathrm{GPA}^{*} \mathrm{SDR}$ & & & $.0043^{*}$ & $.0074^{*}$ \\
\hline $\begin{array}{l}\text { Qualified lower secon- } \\
\text { dary school certificate } \\
{ }^{*} \mathrm{GPA}^{*} \text { SDR }\end{array}$ & & & & $-.0092^{\wedge}$ \\
\hline $\begin{array}{l}\text { Maximum regular } \\
\text { lower school certificate } \\
{ }^{*} \mathrm{GPA}^{*} \mathrm{SDR}\end{array}$ & & & & -.0033 \\
\hline $\begin{array}{l}\text { Migration background } \\
\text { * SDR }\end{array}$ & & & -.0008 & -.0006 \\
\hline $\begin{array}{l}\text { Both parents have no } \\
\text { or lower secondary } \\
\text { school certificate }{ }^{*} \\
\text { SDR }\end{array}$ & & & $.0058^{\wedge}$ & $.0055^{\wedge}$ \\
\hline $\begin{array}{l}\text { Max. parental ISEI < } \\
30 * \text { SDR }\end{array}$ & & & -.0012 & -.0013 \\
\hline \multicolumn{5}{|l|}{ Control variables } \\
\hline $\begin{array}{l}\text { Perceptual speed } \\
\text { (DGFC) }\end{array}$ & $.0250^{* *}$ & $.0120^{\wedge}$ & $.0122^{\wedge}$ & $.0123^{\wedge}$ \\
\hline Reasoning (DGFC) & $.0750^{* * *}$ & $.0170^{*}$ & $.0177^{\star}$ & $.0179^{*}$ \\
\hline Grade in mathematics & $-.0430^{* * *}$ & $-.0314^{\star * \star}$ & $-.0315^{\star * *}$ & $-.0301^{* *}$ \\
\hline Grade in German & $-.0457^{* * *}$ & .0020 & .0021 & .0012 \\
\hline Sex (female) & $-.0812^{* * *}$ & $-.0755^{\star \star \star}$ & $-.0774^{* * *}$ & $-.0793^{* * *}$ \\
\hline $\begin{array}{l}\text { Control for federal } \\
\text { states }\end{array}$ & $\mathrm{x}$ & $\mathrm{x}$ & $\mathrm{x}$ & $\mathrm{x}$ \\
\hline Pseudo $\mathrm{R}^{2}$ & .105 & .233 & .236 & .238 \\
\hline
\end{tabular}

Note. Reference group: Initial entry into transition sector; significance levels: The significance levels refer to the AME coefficients: $\mathrm{p}^{\star * *}<.001,{ }^{* *}<.01,{ }^{\star}<.05, \wedge<.1$; unweighted but imputed data.

M1 shows that the chances of obtaining a training place in the dual system increased with lower regional competition for company-based training among adolescents. For each higher percentage point in the SDR, the average probability of obtaining a dual training place increases by approximately 0.6 percentage points, ceteris paribus.

M2 makes it clear that low-educational qualification, a poorer GPA, and migration background substantially limited the probability of achieving a dual training place.

In M3, it can be seen that the positive influence of the SDR on obtaining a dual training place is also valid when an interaction of SDR and the educational qualification category is generated. In terms of interaction, however, only the interaction term between SDR and the lowest educational qualification category (no or regular lower secondary school certificate) is significant. The associated AME is negative. This means that the probability function of adolescents with no or regular lower secondary school certificates has a lower slope in 
comparison to adolescents with an intermediate secondary school certificate when SDR is increasing. Therefore, Figure 1 illustrates the interaction effect of educational qualification categories and SDR in obtaining a dual training place.

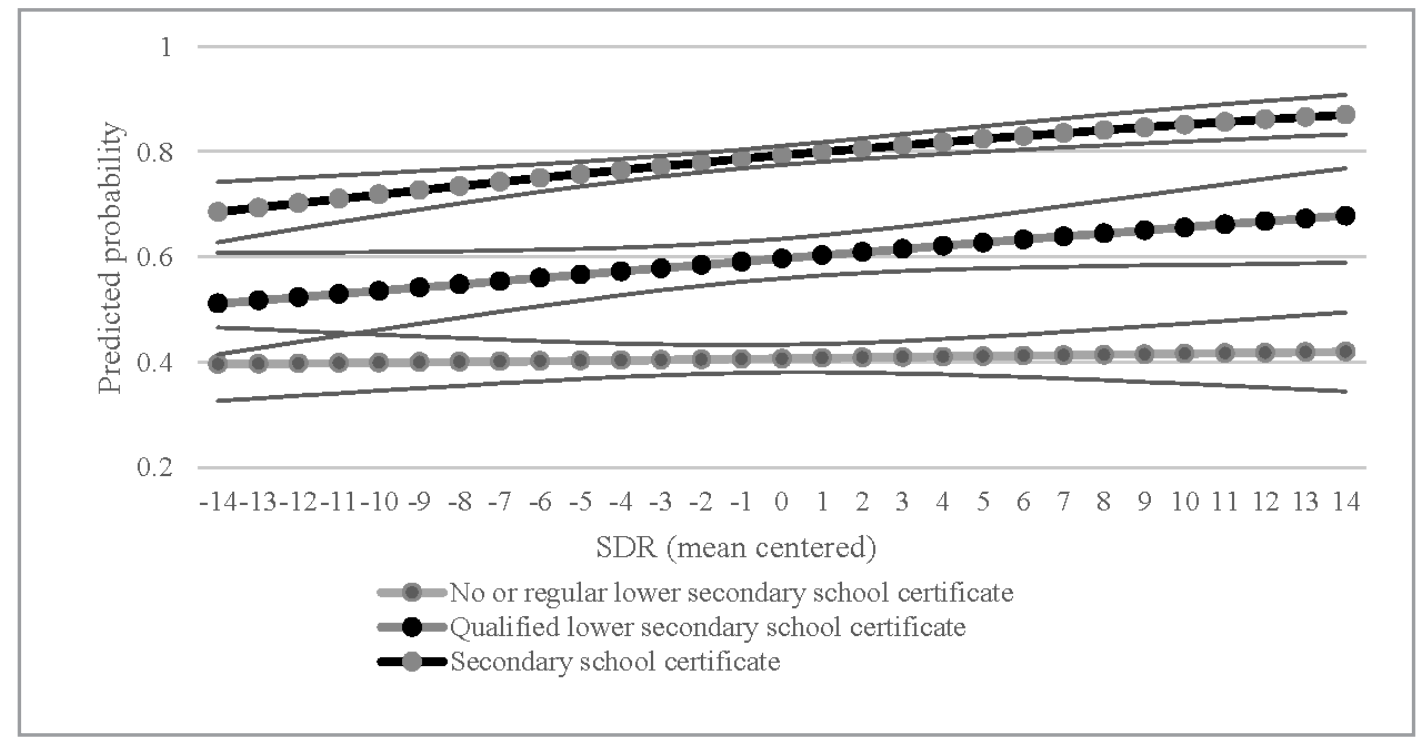

Figure 1: Predicted Probabilities to Obtain a Dual Training Place for the Interaction Terms of Educational Qualification Categories and SDR

Note. Based on the regression model M3; due to the centring of the SDR, no real SDR values can be printed. The 0.0 represent approximately the SDR mean in the non-imputed data set (SDR $=93.60 \%)$; confidence intervals as grey lines.

Considering only the interaction between GPA and SDR (M3), a significant positive interaction term is evident, meaning that the probability of obtaining a dual training place for school-leavers with higher GPAs increases when SDR increases. Figure 2 illustrates this interaction. 


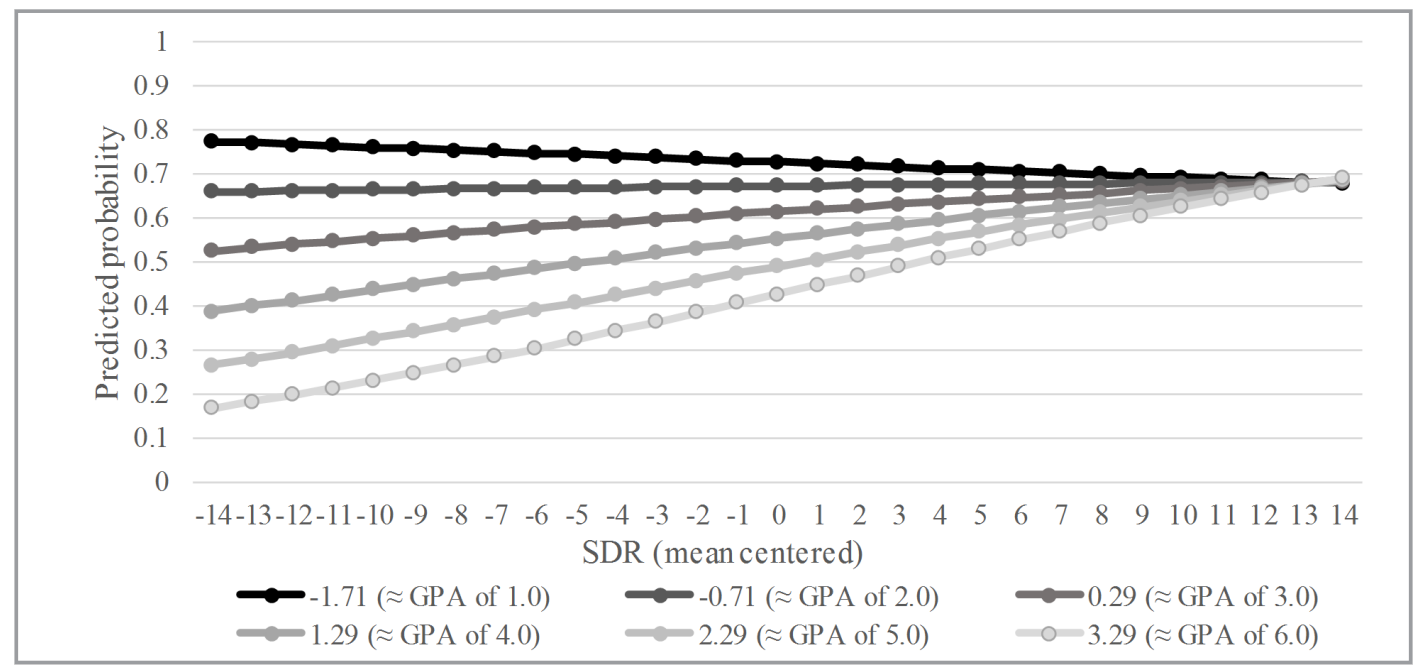

Figure 2: Predicted Probabilities to Obtain a Dual Training Place for the Interaction of GPA and SDR

Note. Based on the regression model M3; due to the centring of the GPA and SDR, no clear grade levels and no real SDR values can be printed; an SDR of 0.0 represents approximately the SDR mean in the non-imputed data set (SDR $=93.60 \%)$; for better legibility without confidence intervals.

M4 extended the previous perspective by an interaction of SDR, educational qualification category and GPA. The interpretation of all interaction terms has to be done with caution because not every term considered in this interaction is significant. For an easier interpretation, Figure 3 visualizes these interaction terms. Here, it becomes clear that adolescents with intermediate secondary school certificates and poorer GPAs (higher GPA value), as well as adolescents with qualified lower secondary school certificates and lower GPAs, benefit by an increase in the SDR. Additionally, adolescents with no or maximum regular lower secondary school certificates could also benefit from an increase in the SDR if they have a poorer GPA. However, Figure 3 reveals that the predicted probability of those adolescents does not reach the predicted probabilities of adolescents with higher school certificates in obtaining a dual training place over most SDR values. 


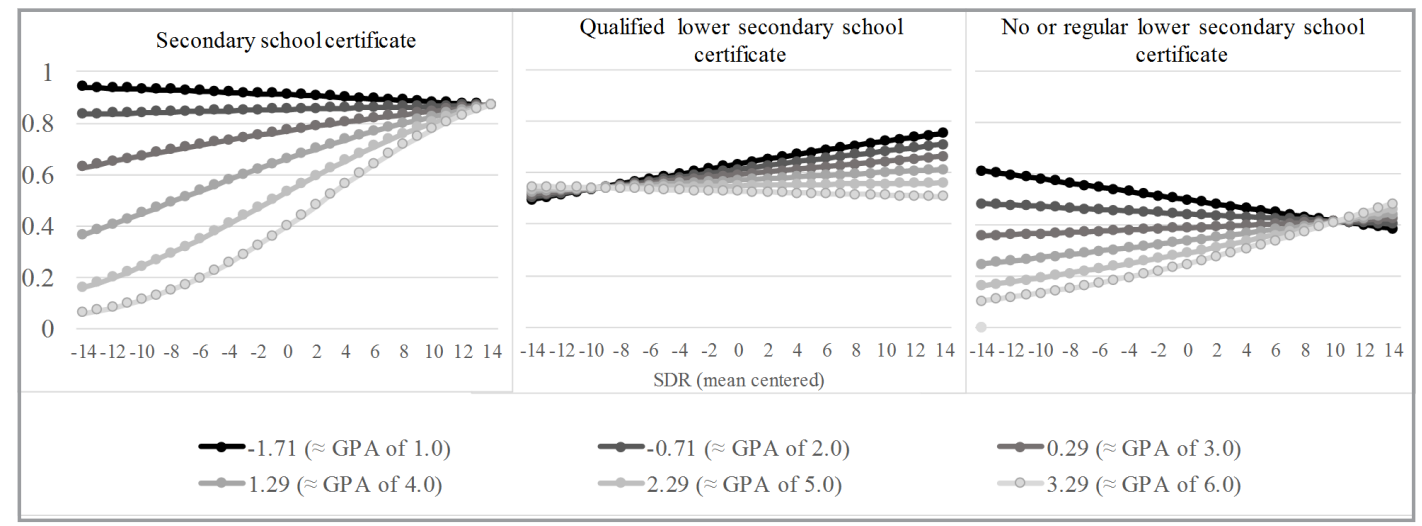

Figure 3: Predicted Probabilities of Obtaining a Dual Training Place for the Interaction of Educational Qualification Categories, GPA and SDR

Note. Based on the regression model M3; due to the centring of the SDR, no real SDR values can be printed. The 0.0 represent approximately the SDR mean in the non-imputed data set (SDR $=93.60 \%$ ); for better legibility without confidence intervals.

Regarding the influence of social disparities, two significant effects exist in the regression analysis. First, there is a general significant discrimination effect for adolescents with a migration background. For this group, the probability of obtaining a dual training place is on average 6.7 percentage points lower than for adolescents without a migration background, ceteris paribus (based on M2). However, the interaction between SDR and a migration background is not significant. Thus, the benefits of a lower SDR have an equal impact on adolescents with a migration background in comparison to those without a migration background. Figure 4 illustrates this effect. Second, a significant interaction term between SDR and the variable, whether both parents achieve no or a lower secondary educational school certificate is measurable. This effect is positive, which means that the slope of predictive probabilities depending on SDR for this group is higher than for adolescents whose parents achieved higher school certificates. However, the relating significance level is only weak $(<10 \%)$ and should be interpreted with caution. For parental ISEI-08, no effects are evident. 


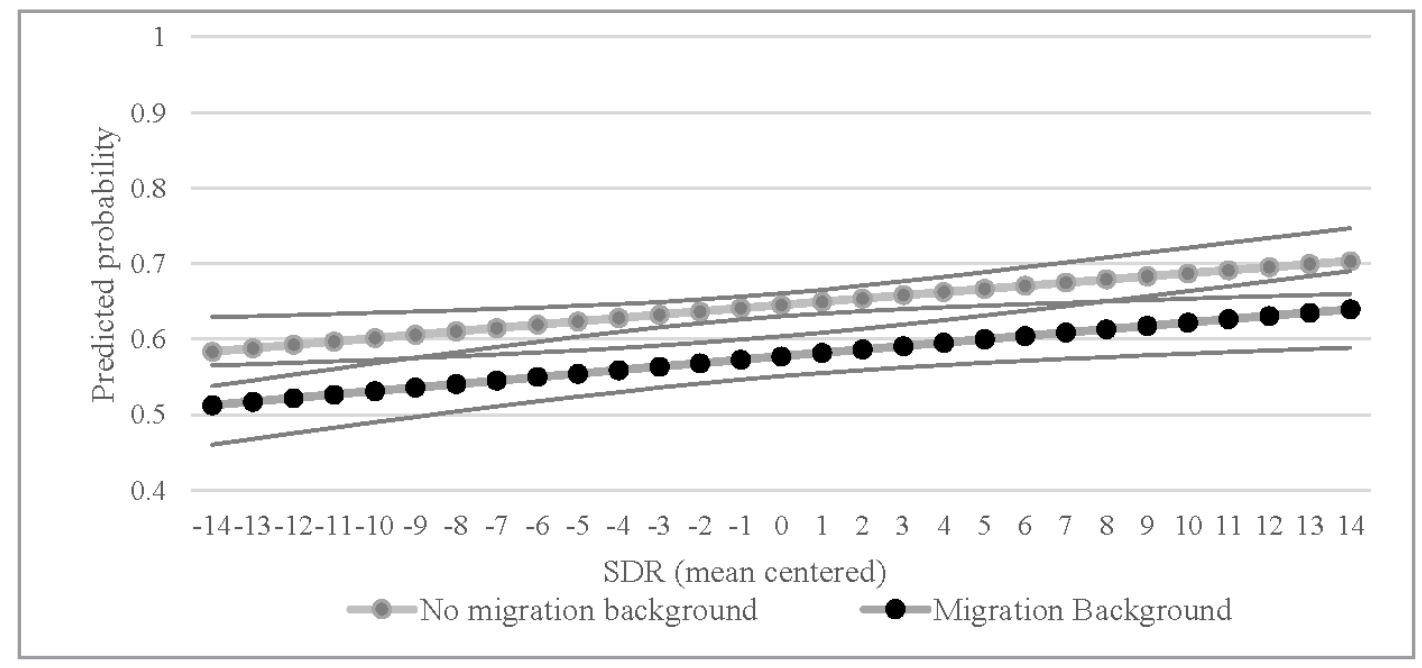

Figure 4: Predicted Probabilities to Obtain a Dual

Training Place Depending on Migration Background

Note. Based on the regression model M3; due to the centring of the SDR, no real SDR values can be printed. The 0.0 represent approximately the SDR mean in the non-imputed data set (SDR = 93.60\%); confidence intervals as grey lines.

To prove H4, Table 3 shows the results of the multinomial logistic regression. The results make it clear that any advantages in obtaining a dual training place due to increasing SDR is significant and apparent for occupations that are characterized by a share of more than $5 \%$ of vacant training places.

Table 3: Multinomial Logistic Regression to Explain the Initial Entry of 9th and 10th-Grade School-Leavers Into Dual Training Places for Different Clusters of Hiring Challenges in Training Occupations

\begin{tabular}{|c|c|c|c|}
\hline Model & $\begin{array}{l}\text { Low hiring challenges } \\
\text { (share of vacant training } \\
\text { places }<=2.5 \% \text { ) }\end{array}$ & $\begin{array}{l}\text { Intermediate hiring } \\
\text { challenges }(2.5 \%< \\
\text { share of vacant training } \\
\text { places }<=5.0 \%)\end{array}$ & $\begin{array}{l}\text { Higher hiring challenges } \\
\text { (share of vacant training } \\
\text { places }>5 \% \text { ) }\end{array}$ \\
\hline \multicolumn{4}{|l|}{ Regional training market condition } \\
\hline SDR & -.0014 & .0033 & $.0055^{*}$ \\
\hline \multicolumn{4}{|c|}{ Educational qualification (reference category for the school certificate: intermediate secondary school certificate) and GPA } \\
\hline $\begin{array}{l}\text { Qualified lower secondary school } \\
\text { certificate }\end{array}$ & $-0.1263^{* * *}$ & $-.0484^{* *}$ & -.0005 \\
\hline $\begin{array}{l}\text { No or regular lower secondary school } \\
\text { certificate }\end{array}$ & $-0.2194^{* * *}$ & $-.0986^{* * *}$ & $-.0596 * * *$ \\
\hline GPA & $-.0930^{* * *}$ & .0040 & $.0296 \wedge$ \\
\hline \multicolumn{4}{|l|}{ Social background characteristics } \\
\hline Migration background & $-.0368^{* *}$ & -.0125 & -.0184 \\
\hline
\end{tabular}




\begin{tabular}{|c|c|c|c|}
\hline $\begin{array}{l}\text { Both parents have no or lower } \\
\text { secondary school certificate }\end{array}$ & $-.0159^{\star}$ & .0187 & .0171 \\
\hline Max. Parental ISEI $<30$ & $-.0259^{\wedge}$ & .0016 & -.0009 \\
\hline \multicolumn{4}{|l|}{ Interaction terms } \\
\hline $\begin{array}{l}\text { Qualified lower secondary school } \\
\text { certificate }{ }^{\star} \text { SDR }\end{array}$ & -.0028 & .0028 & -.0023 \\
\hline $\begin{array}{l}\text { No or regular lower secondary school } \\
\text { certificate }{ }^{*} \text { SDR }\end{array}$ & -.0020 & .0020 & $-.0061^{* *}$ \\
\hline $\mathrm{GPA} * \mathrm{SDR}$ & -.0001 & .0013 & $.0030^{\wedge}$ \\
\hline Migration background ${ }^{*}$ SDR & .0002 & -.0020 & .0010 \\
\hline $\begin{array}{l}\text { Both parents have no or lower } \\
\text { secondary school certificate }{ }^{\star} \text { SDR }\end{array}$ & .0061 & -.0018 & .0017 \\
\hline Max. parental ISEI $<30 *$ SDR & .0016 & .0004 & -.0032 \\
\hline \multicolumn{4}{|l|}{ Control variables } \\
\hline Perceptual speed (DGFC) & .0025 & .0021 & .0081 \\
\hline Reasoning (DGFC) & $.0142^{\star}$ & $.0110^{\wedge}$ & -.0070 \\
\hline Grade in mathematics & $-.0317^{\star * *}$ & -.0118 & .0125 \\
\hline Grade in German & .0137 & -.0062 & -.0062 \\
\hline Sex (female) & $-.0828^{\star * *}$ & $-.0718^{\star * *}$ & $.0754^{* * *}$ \\
\hline Control for federal states & $\mathrm{x}$ & $\mathrm{x}$ & $\mathrm{x}$ \\
\hline Pseudo $\mathrm{R}^{2}$ & .071 & & \\
\hline
\end{tabular}

ISEI-08 values for the clusters with low und intermediate hiring challenges differ significantly with the cluster with higher hiring challenges (evaluated by comparison of means, both tests are significant on $\mathrm{p}<.001$ ). For a more straightforward interpretation of this effect, Figure 5 includes box plots that compare the corresponding ISEI-08 values of the hiring challenge clusters in the dataset. It becomes clear that adolescents in occupations with more than 5 percent of vacant training places have remarkably lower ISEI-08 values. Considering the results of Table 3, this indicates that easier entry conditions for dual training places due to a lower SDR apply primarily for low-prestige occupations. 


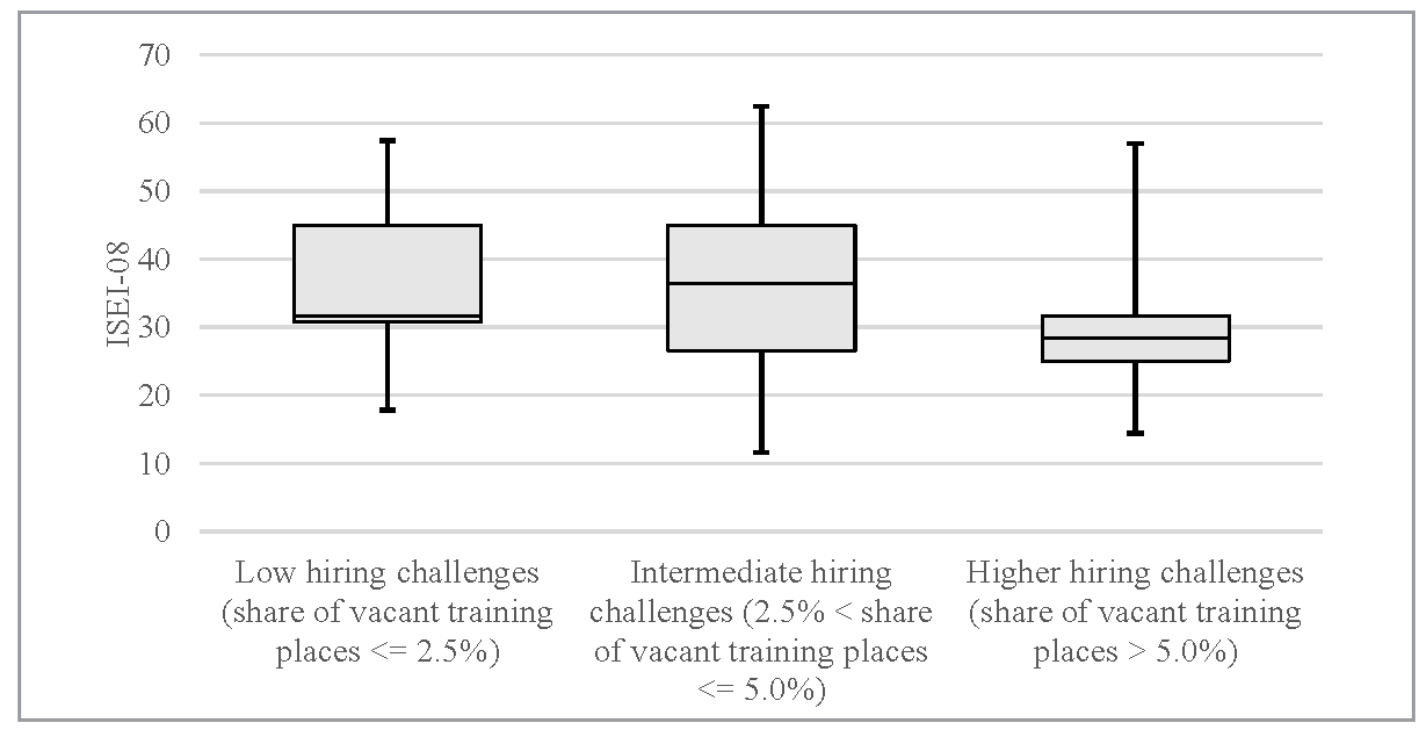

Figure 5: Box Plot to Visualize Distributions of ISEI-08 Values in Hiring Challenge Clusters Note. Due to outlier, the upper whisker is reduced to a maximum of $97.5 \%$ of the ISEI-08 distribution range.

\section{Discussion}

The analyses make it clear that the chances of obtaining a dual training place differ between regional training markets and increase in competitive training markets with less demand. This is in line with H1 and with previous research results (Beicht \& Walden, 2018; Lex \& Zimmermann, 2011). Nevertheless, the results reveal that the influence of the regional training market condition becomes more apparent if the interactions with individual characteristics of adolescents are modelled. In particular, beneficiaries are better-qualified adolescents. First, adolescents with an intermediate educational qualification (intermediate secondary school certificate) have the highest chances of obtaining a training contract in the dual system, even if competition for company-based training among adolescents has decreased. Second, the AME of adolescents in the lowest educational category (no or regular lower secondary school certificate) is significantly lower than for adolescents with an intermediate educational qualification (intermediate secondary school certificate) in regard to obtaining a dual training place if competition for company-based training among adolescents decreased. This result is consistent with $\mathrm{H} 2 \mathrm{a}$.

The results in this article also allow for a more differentiated view in comparison to previous research findings of the effects of regional differences in the training market. The interaction of grades and the regional competitive situation in the training market is especially remarkable. If the predictive probability of obtaining a dual training place is plotted according 
to GPA levels and SDR for each educational qualification category (Figures 3) two effects become apparent. Adolescents with poor GPAs and intermediate educational qualifications, in particular, benefit the most from decreased competition for company-based training among adolescents, which is in line with H2b. For low-qualified adolescents, it depends on their educational qualification category. The results for adolescents with no or regular lower secondary school certificates show only enhanced opportunities, even in cases where they have poorer GPAs. Nevertheless, their probability of obtaining a dual training place generally remains under the level of both higher-level educational qualification categories. In sum, the overall results show that applicant hierarchies (Thurow, 1972, 1975) are intact even in the case of lower competition for company-based training among adolescents. This also means that the integration of low-qualified adolescents into company-based training will rarely improve if competition for company-based training among adolescents decreases.

Different situations in the training market do not seem to influence the degree of social disparities in accessing company-based training. In other words, when the competition for training places is low, the likelihood of entering company-based training increases to the same extent for both those who are more likely to face disparities in VET access (adolescents of low-SES or with migration background) and for those who are not (adolescents of higher SES or no migration background). Thus, the findings cannot support H3. Contrarily, the results show little evidence for $\mathrm{H} 3$, as it applies to parental education. When training competition for training places is low, the likelihood of company-based training access increases to a greater extent for adolescents whose parents were low-educated than for adolescents whose parents were highly educated. It seems that the well-known disadvantages of low parental education in access to VET (Seeber et al., 2019a) do not exist when competition for training is low.

However, the analyses also illustrate that advantages in obtaining a dual training place when lower competition for company-based training among adolescents arise especially in occupations that are characterized by hiring challenges (confirmation of H4). Relating the ISEI-08 values of those occupations indicates that those occupations characterized by low prestige (against the background of the expected level of education and future income of those occupations). This result is noteworthy because it shows that easier access to training places due to relaxing market conditions should not always be interpreted as a gain in regards to opportunity. Without participation in further training, trainees influenced by those advantages could be affected in their future career path with lower monetary outcomes as well as social participation. However, this hypothesis requires further research.

Some further effects are remarkable in the order of the results of different clusters of hiring challenges in training occupations. Regarding the access to lower-prestige occupations (training occupations with intermediate and higher hiring challenges), the migration effect is not significant. This is noteworthy because this result indicates that an occupationally 
based segmentation effect exists for young migrants in company-based training. Therefore, an occupational-based analysis of migration effects needs further engagement by research.

In addition, this study did not control for adolescents' educational and occupational choices. Adolescents (and their parents) likely consider the regional opportunity structures in regard to deciding whether to apply for a training place (Glauser \& Becker, 2016). Therefore, further research is necessary on the links between the educational and occupational choices of adolescents on the one hand, and regional disparities in company-based training access on the other. Additionally, the influence of market-induced ease-of-access in regards to training offers on actual training success, labour market assessments, as well as career development, have received little attention in research. Regarding the effects of this study, less-demand competitive training markets could foster mismatches and therefore, frictions in the training process as well as influencing career development.

We assume that our results allow international implications. Regional differences in economic and demographic factors as well as limited geographical mobility of adolescents do not only exist in Germany but also in other countries. Therefore, it would be promising for further international research on the access to VET to additionally account for regional training market conditions.

Moreover, the results are important for the understanding of developments of the training market. Trends such as technological and sustainability transformation, structuraleconomical change or global crisis like the COVID-19-Pandemic can change the supply for as well as the demand for training places. On the one hand these trends and challenges lead to changing qualification profiles and competences that are required of applicants. On the other hand, adolescents' expectations of VET can change. In this vein, training systems are facing increasing pressure: In many countries within the OECD, a clear change in educational structures is visible (for example higher rates of tertiary education) (Musset \& Kurekova, 2018; OECD, 2014). As higher education and VET compete for potential demanders (Powell \& Solga 2010), the trend towards higher qualification can limit the demand for training places, especially in countries with strong VET traditions. By decreasing the demand for companybased training places this development may lead to an excess supply of training places and, thus, intensify the (regional) competition in the hiring of qualified trainees. However, in the long term, this trend may also force more significant changes in the recruitment strategies of companies, which is an additional future research objective.

Furthermore, educational policies for enhancing matching quality should be tailored to prevent developments of the training market. For example, programs that enhance the geographical mobility may be promising for those adolescents in training markets with excess demand for training places. Another point concerns potential consequences of the training process by a downgrading of hiring standards, because low-skilled adolescents have the highest risk of a premature contract termination (Beicht \& Ulrich, 2009; Rohrbach-Schmidt \& 
Uhly, 2015). Therefore, strategies to promote the quality of training and professionalism of personnel for in-company vocational training should be critically reflected. Furthermore, in order to secure demand for skilled labour in the long term, strategies should be considered to increase the attractiveness of VET.

\section{Acknowledgment}

This paper uses data from the National Educational Panel Study (NEPS): Starting Cohort Grade 9, https://doi.org/10.5157/NEPS:SC4:10.0.0. From 2008 to 2013, NEPS data was collected as part of the Framework Program for the Promotion of Empirical Educational Research funded by the German Federal Ministry of Education and Research (BMBF). As of 2014, NEPS is carried out by the Leibniz Institute for Educational Trajectories (LIfBi) at the University of Bamberg in cooperation with a nationwide network.

\section{References}

Autorengruppe Bildungsberichterstattung. (2012). Bildung in Deutschland 2012. Ein indikatorengestützter Bericht mit einer Analyse zur kulturellen Bildung im Lebenslauf [Education in Germany 2012: An indicator-based report including an analysis of arts education throughout the life course]. Bertelsmann.

Autorengruppe Bildungsberichterstattung. (2018). Bildung in Deutschland 2018. Ein indikatorengestützter Bericht mit einer Analyse zu Wirkungen und Erträgen von Bildung [Education in Germany 2018: An indicator-based report with an analysis on the effects and returns of education]. Bertelsmann. https://doi.org/10.3278/6001820fw

Autorengruppe Bildungsberichterstattung. (2020). Bildung in Deutschland 2020. Ein indikatorengestützter Bericht mit einer Analyse zu Bildung in einer digitalisierten Welt [Education in Germany 2020: An indicator-based report with an analysis on education in a digitalized world]. Bertelsmann. https://doi.org/10.3278/6001820gw

Baethge, M., Achtenhagen, F., Arends, L., Babic, E., Baethge-Kinsky, V., \& Weber, S. (2006). PISA-VET. A Feasibility-study. Franz Steiner.

Baethge, M., Maaz, K., Seeber, S., Jäger, D., Kühne, S., Lenz, B., Michaelis, C., Wieck, M., \& Wurster, S. (2016). Ländermonitor berufliche Bildung 2015: Chancengerechtigkeit und Leistungsfähigkeit im Vergleich der Bundesländer [Vocational Training Report 2015: Economic performance and social equality of opportunities of the vocational training system at federal state level]. Bertelsmann Stiftung.

Beicht, U., \& Ulrich, J. G. (2009). The course of training and the transition to employment. A comparison of participants in in-company and school-based vocational training. Berufsbildung in Wissenschaft und Praxis (BWP), special edition, 27-31. https://www.bibb.de/dokumente_archiv/pdf/ a12bwp_special-edition_2009_beicht_ulrich.pdf 
Beicht, U., \& Walden, G. (2017). Transitions of young migrants to initial vocational education and training in Germany: The significance of social origin and gender. Journal of Vocational Education \& Training, 69(3), 424-449. https://doi.org/10.1080/13636820.2016.1275032

Beicht, U., \& Walden, G. (2018). Neue Bildungsexpansion und Verdrängungseffekte in der betrieblichen Ausbildung [New educational expansion and crowding-out effects in company based training]. Sozialer Fortschritt, 67, 141-172. https://doi.org/10.3790/sfo.67.3.141

Beicht, U., \& Walden, G. (2019). Transition to company-based vocational training in Germany by young people from a migrant background - The influence of region of origin and generation status. International Journal for Research in Vocational Education and Training, 6(1), 20-45. https://doi. org/10.13152/IJRVET.6.1.2

Blossfeld, H.-P., Roßbach, H.-G., \& von Maurice, J. (2011). Education as a lifelong process - The German National Educational Panel Study (NEPS). Zeitschrift für Erziehungswissenschaft, special issue, 14. https://doi.org/10.1007/978-3-658-23162-0

Borjas, G. J. (2013). Labor economics. McGraw-Hill/Irwin.

Boudon, R. (1974). Education, Opportunity, and Social Inequality. Wiley.

Brown, S. D., \& Lent, R. W. (2013). Career development and counseling: Putting theory and research to work (2nd ed.). Wiley.

Bundesinstitut für Berufsbildung. (2013). Datenreport zum Berufsbildungsbericht 2013: Informationen und Analysen zur Entwicklung der beruflichen Bildung [Data report on the 2013 report on vocational education and training: Information and analyses on the development of vocational education and training]. Bertelsmann.

Bundesinstitut für Berufsbildung. (2018). Datenreport zum Berufsbildungsbericht 2018: Informationen und Analysen zur Entwicklung der beruflichen Bildung [Data report on the 2018 report on vocational education and training: Information and analyses on the development of vocational education and training]. Budrich.

Busse, R. (2020a). Der Einfluss persönlicher, sozialer, institutioneller und regionaler Bedingungen auf den Bildungsverlauf von Schulabgängerinnen und -abgängern ohne Studienberechtigung [The influence of personal, social, institutional and regional factors on the educational pathways of school leavers without university entrance certificate: Analyses based on the German National Educational Panel Study (NEPS)]. Zeitschrift für Berufs- und Wirtschaftspädagogik, 116(1), 26-56. https:// doi.org/10.25162/zbw-2020-0002

Busse, R. (2020b). Übergangsverläufe am Ende der Sekundarstufe I: Erklärungsansätze für soziale und migrationsbezogene Ungleichheiten [Educational trajectories after secondary school: Explaining social and migration-related inequalities]. wbv. https://doi.org/10.3278/6004818w

Diamond, P. A. (1982). Wage determination and efficiency in search equilibrium. The Review of Economic Studies, 49(2), 217-227. https://doi.org/10.2307/2297271

Eckelt, M., \& Schauer, J. (2019). Der Einfluss des regionalen Ausbildungsangebots auf die Übergangswahrscheinlichkeit in Ausbildung nicht-studienberechtigter Jugendlicher [The influence of the regional supply of training positions on the transition to vocational education and training for school leavers without university entrance certificate]. Zeitschrift für Berufs-und Wirtschaftspädagogik, 115(3), 447-485. https://doi.org/10.25162/zbw-2019-0019

European Centre for the Development of Vocational Training. (2013). Labour market outcomes of vocational education in Europe: Evidence from the European Union labour force survey. Publications Office of the European Union. https://doi.org/10.2801/44683 
European Centre for the Development of Vocational Training. (2018). Apprenticeship schemes in European countries: A cross-nation overview. Publications Office. https://doi.org/10.2801/722857

European Commission. (2012). Apprenticeship supply in the Member States of the European Union. Publications Office of the European Union.

Forsblom, L., Negrini, L., Gurtner, J. L., \& Schumann, S. (2016). Dropouts in Swiss vocational education and the effect of training companies' trainee selection methods. Journal of Vocational Education \& Training, 68(4), 399-415. https://doi.org/10.1080/13636820.2016.1222596

Ganzeboom, H. B. (2010). A new international sozio-economic Index (ISEI) of occupational Status for the international standard classification of occupation 2008 (ISCO-08) constructed with data from the ISSP 2002-2007: With an analysis of quality of occupational measurement in ISSP. Annual Conference of International Social Survey Programme. http://www.harryganzeboom.nl/Pdf/2010\%20 -\%20Ganzeboom-ISEI08-ISSP-Lisbon-(paper).pdf

Ganzeboom, H. B., de Graaf, P. M., \& Treiman, D. J. (1992). A standard international socio-economic index of occupational status. Social Science Research, 21(1), 1-56. https://doi.org/10.1016/0049089X(92)90017-B

Glauser, D., \& Becker, R. (2016). VET or general education? Effects of regional opportunity structures on educational attainment in German-speaking Switzerland. Empirical Research in Vocational Education and Training, 8(1), 1-25. https://doi.org/10.1186/s40461-016-0033-0

Goastellec, G., \& Ruiz, G. (2015). Finding an apprenticeship: Hidden curriculum and social consequences. Frontiers in Psychology, 6(1441), 1-13. https://doi.org/10.3389/fpsyg.2015.01441

Haberkorn, K., \& Pohl, S. (2013). Cognitive basic skills - Data in the scientific use file. https://www. neps-data.de/Portals/0/NEPS/Datenzentrum/Forschungsdaten/SC3/com_cogbasic2013_en.pdf

Hillmert, S., Hartung, A., \& Weßling, K. (2017). A decomposition of local labour-market conditions and their relevance for inequalities in transitions to vocational training. European Sociological Review, 33(4), 534-550. https://doi.org/10.1093/esr/jcx057

Holland, J. L. (1997). Making vocational choices: A theory of vocational personalities and work environments (3rd ed.). Psychological Assessment Resources.

Holtmann, A. C., Menze, L., \& Solga, H. (2017). Persistent disadvantages or new opportunities? The role of agency and structural constraints for low-achieving adolescents' school-to-work transitions. Journal of Youth and Adolescence, 46(10), 2091-2113. https://doi.org/10.1007/s10964-017-0719-z

Jaccard, J., Turrisi, R., \& Jaccard, J. (2003). Interaction effects in multiple regression (2nd ed). Sage University Papers Series on Quantitative Applications in the Social Sciences. Sage. https://doi. org/10.4135/9781412984522

Kleinert, C., Vosseler, A., \& Blien, U. (2018). Classifying vocational training markets. The Annals of Regional Science, 61(1), 31-48. https://doi.org/10.1007/s00168-017-0856-Z

Lent, R. W., Brown, S. D., \& Hackett, G. (1994). Toward a unifying social cognitive theory of career and academic interest, choice, and performance. Journal of Vocational Behavior, 45, 79-122. https:// doi.org/10.1006/jvbe.1994.1027

Lex, T., \& Zimmermann, J. (2011). Wege in Ausbildung [Pathways into vocational training]. Zeitschrift für Erziehungswissenschaft, 14(4), 603-627. https://doi.org/10.1007/s11618-011-0250-z

Michaelis, C. (2017). Zur Steuerung und Entwicklung des Schulberufssystems unter Berücksichtigung rechtlicher sowie ausbildungsmarktabhängiger Einflüsse [Operation and development of the school-based VET system, taking into account legal and training market influences]. Recht der Jugend und des Bildungswesens, 65(4), 406-424. https://doi.org/10.5771/0034-1312-2017-4-406 
Mortensen, D. T. (1982). The matching process as a non-cooperative/bargaining game. In J. J. McGall (Ed.), The economics of information and uncertainty (pp. 233-258). University of Chicago Press.

Musset, P., \& Kurekova, L. M. (2018). Working it out: Career guidance and employer engagement. OECD Publishing. https://doi.org/10.1787/51c9d18d-en

Organisation for Economic Co-operation and Development. (2010). Learning for jobs. OECD. https:// doi.org/10.1787/9789264087460-en

Organisation for Economic Co-operation and Development. (2014). Education at a glance OECD indicator. OECD Publishing. https://doi.org/10.1787/eag-2014-en

Paulus, W., \& Matthes, B. (2013). Klassifikation der Berufe: Struktur, Codierung und Umsteigeschlüssel [Classification of occupations: structure, coding and conversion key]. Bundesagentur für Arbeit. http://213.241.152.197/fdz/reporte/2013/MR_08-13.pdf

Petrongolo, B., \& Pissarides, C. A. (2001). Looking into the black box: A survey of the matching function. Journal of Economic Literature, 39(2), 390-431. https://doi.org/10.1257/jel.39.2.390.

Poulsen, S. B., \& Eberhardt, C. (2016). Approaching apprenticeship systems from a European perspective. $\mathrm{BiBB}$.

Powell, J. J., \& Solga, H. (2010). Analyzing the nexus of higher education and vocational training in Europe: A comparative-institutional framework. Studies in Higher Education, 35(6), 705-721. https://doi.org/10.1080/03075070903295829

Protsch, P., \& Dieckhoff, M. (2011). What matters in the transition from school to vocational training in Germany: Educational credentials, cognitive abilities or personality? European Societies, 13(1), 69-91. https://doi.org/10.1080/14616696.2010.540352

Protsch, P., \& Solga, H. (2015). How employers use signals of cognitive and noncognitive skills at labour market entry: Insights from field experiments. European Sociological Review, 31(5), 521532. https://doi.org/10.1093/esr/jcv056

Rohrbach-Schmidt, D., \& Uhly, A. (2016). Betriebliches Vertragslösungsgeschehen in der dualen Berufsausbildung. Eine Analyse des BIBB-Betriebspanels zu Qualifizierung und Kompetenzentwicklung [Company contract termination in dual vocational education and training. An Analysis of the BIBB Company Panel on Qualification and Competence Development]. Empirische Pädagogik, $30,372-401$.

Schuler, H., Hell, B., Trapmann, S., Schaar, H., \& Boramir, I. (2007). Die Nutzung psychologischer Verfahren der externen Personalauswahl in deutschen Unternehmen: Ein Vergleich über 20 Jahre [Use of personnel selection instruments in German organizations in the last 20 years]. Zeitschrift für Personalpsychologie, 6(2), 60-70. https://doi.org/10.1026/1617-6391.6.2.60

Seeber, S., Busse, R., Michaelis, C., \& Baethge, M. (2019a). Migration in der beruflichen Bildung: Herausforderungen für die Integration von zugewanderten schutz- und asylsuchenden Jugendlichen [Migration in vocational eduation and training: Challenges of the integration of asylum seekers and refugees]. Zeitschrift für Erziehungswissenschaft, 22, 71-99. https://doi.org/10.1007/ s11618-019-00890-4

Seeber, S., Wieck, M., Baethge-Kinsky, V., Boschke, V., Michaelis, C., Busse, R., \& Geiser, P. (2019b). Ländermonitor berufliche Bildung 2019: Ein Vergleich der Bundesländer mit vertiefender Analyse zu Passungsproblemen im dualen System [Vocational training report 2019: In-depth analysis of matching problems on the regional training market]. https://doi.org/10.3278/6004750w

Solga, H., Protsch, P., Ebner, C., \& Brzinsky-Fay, C. (2014). The German vocational education and training system. WZB. https://bibliothek.wzb.eu/pdf/2014/i14-502.pdf 
Spence, M. (1973). Job market signaling. The Quarterly Journal of Economics, 87(3), 355-374. https:// doi.org/10.2307/1882010

Steinhauer, H. W., \& Zinn, S. (2016). NEPS technical report for weightng: Weightng the sample of starting cohort 4 of the National Educatonal Panel Study (Wave 1 to 6). LifBi. https://www.neps-data.de/ Portals/0/Survey\%20Papers/SP_II.pdf

Thurow, L. C. (1972). Education and economic equality. The public interest, 28, 66-81.

Thurow, L. C. (1975). Generating inequality. Basic books.

Weßling, K., Hartung, A., \& Hillmert, S. (2015). Spatial structure counts: The relevance of regional labour-market conditions for educational transitions to vocational training. Empirical Research in Vocational Education and Training, 7(1), 12. https://doi.org/10.1186/s40461-016-0028-x

Wieling, M., \& Borghans, L. (2001). Descrepancies between supply and demand and adjustment processes in the labour market. Labour, 15(1), 33-56. https://doi.org 10.1111/1467-9914.00154

\section{Biographical Notes}

Dr Christian Michaelis is an assistant professor at the Chair of Business Education and Human Resource Development at the Georg-August University of Goettingen. His research focus lies on monitoring in Vocational Education and Training (VET), competence diagnostics in VET as well as vocational education for a sustainable development.

Dr Robin Busse is an assistant professor at the Chair of Business Education and Human Resource Development at the Georg-August University of Goettingen. His main research topics are social and migration-related disparities at the transition from school to Vocational Education and Training. 